Journal of Applied Finance \& Banking, Vol. 11, No. 1, 2021, 41-60

ISSN: 1792-6580 (print version), 1792-6599(online)

https://doi.org/10.47260/jafb/1113

Scientific Press International Limited

\title{
The Internationalization-Performance Relationship of Small-and-Medium-sized Enterprises: The Case of Taiwan's ESCO Industry
}

\author{
Li-Jen Yeh', Jia-Ying $\mathrm{Hu}^{2}$ and Zongyi Chen ${ }^{3}$
}

\begin{abstract}
We analyze the international output patterns with Taiwan's energy service companies (ESCOs) investigated in 2016 2019. Due to the finite demand in Taiwan energy-saving market, half of Taiwanese ESCOs develop Asia Pacific markets with international trade, alliance and enterprises group. We derive and confirm some hypotheses about international developing patterns of Taiwanese ESCOs.

The First is that those firms with more specific resources will be easier to promote the internationalization of energy-saving businesses. The specific resources are confirmed as firm capital, annual ESCO sales, net income ratio, annual growth rate, energy saving rate. Secondly, if the degree of internationalization of ESCOs is greater, the overall profitability is also relatively higher. The third, the relationship between internationalization and profitability of ESCOs displays a non-linear trend which means when the export ratio is low, the profit from energy service projects increases; however, when the ratio exceeds the optimal point, about $49.584 \% \sim 54.323 \%$, it will reveals a reversed phenomenon due to high overseas operation costs.
\end{abstract}

JEL classification numbers: F23, F37.

Keywords: Energy Services Companies, Internationalization, Output Patterns, Mediational Effect.

\footnotetext{
${ }^{1}$ Department of Banking and Finance, Shih Chien University.

2 Department of Banking and Finance, Shih Chien University.

3 Taiwan Green Productivity Foundation.
}

Article Info: Received: September 24, 2020. Revised: October 8, 2020.

Published online: October 13, 2020. 


\section{Introduction}

It is increasingly clear that energy saving can bring numerous economic and environmental benefits. While energy efficiency is improving, its impacts on global business activities are too huge to be easily measured. To encourage investment in energy-efficiency projects, the energy performance contracts has been introduced in many countries through energy services companies (ESCOs) that help implementing energy-saving activities with zero initial investment by end-users. ESCOs are those companies that conduct energy-efficiency projects by guaranteeing energy savings, and associated design and installation services (Zheng et al., 2018). ESCOs usually using an energy performance contract (EPC). EPCs incentivize ESCOs to identify and implement energy efficiency opportunities. Under some EPCs, ESCOs provide ongoing operation and maintenance service for energy-saving projects. On worldwide average, ESCO projects deliver energy savings of about 25\% (International Energy Agency, 2018)

According to the data of Energy Efficiency Market Report 2018, global energy efficiency investment grew marginally in 2017, up by 3\% to USD 236 billion. China is the world's main energy consumer. U.S.A. and European energy service companies (ESCOs) have begun to explore actively to overseas, especially to mainland China market. Recently, their energy saving and business performances were significant and felt recognized by Asia Pacific countries. Despite the needs of many countries for ESCO involvement, international ESCOs face many challenges and political, financial and technical impediments. Although ESCOs treat internationalization as important strategic expansion to repay their initial investment, most of them pursue international projects opportunities very selectively due to huge oversea costs and risks.

In 2005, there were only 20 ESCOs in Taiwan, but after the government promoting the programs, the number of ESCOs significantly increases to over three hundreds on February 2019. However, Taiwan's ESCOs are still in the early and middle stages of development. The scale of energy efficiency is small and the manufacturers or end-users are mostly medium-sized enterprises. The industrial output value is estimated to grow to US\$ 539.00 million in 2019 (Yeh, 2019). The main reason for the $10.24 \%$ growth rate should be related to the promotion of new energy policy promoted by governments at all levels in Taiwan. Their developing direction includes: "improve energy efficiency to achieve overall energy saving" policy.

Energy saving and carbon reduction have become the global industrial developing trend. Although the United States and China are large countries in the development of energy-saving industries, the geographical location of the United States is far from Taiwan. ESCOs in Taiwan are dominated by small-and-medium-sized enterprises, the international output cost to North America is quite large. Moreover, the cultural background is the similar between China and Taiwan, though their international trades have been fluctuating drastically. Is there any other regional markets suitable for the development of ESCOs in Taiwan? As our study observe, the ASEAN 10 (Southeast Asia) energy-saving markets are huge, but the ESCO 
industry is not yet mature (especially for smart cities, energy-efficiency technologies and ICT applications). Relatively speaking, Taiwan ESCOs own technical and financial advantages compared to Asian ESCOs, but lack international markets passageway.

In addition, according to the internationalization theory, the degree of internationalization will affect the financial performance of enterprises. Therefore, which oversea markets are suitable for ESCOs in Taiwan to leave for? How can they set up the appropriate degree of internationalization? Or what are the key influential capabilities for this industrial exports?

This research is composed of five sections. The introduction will be discussed in the first section. The literature and empirical hypothesis of international exporting issues are enunciated in section two. The third section discusses our research methodology and the structure of empirical estimation. Then, the fourth section is the empirical analysis of the international output patterns of ESCOs and mediational effects. Finally, the fifth section is the discussion of management implications.

\section{Literature review}

The natural resources in Taiwan are limited, and the domestic consumer market cannot meet the needs of current corporate growth in ESCO industry. As a result, Taiwanese companies had to develop a close relationship with international markets. In fact, the forms of industrial internationalization in Taiwan have become quite diversified, which vary from international trade to cross-boundary strategic alliance, furthermore to foreign direct investment. Over the past two decades, China and Southeast Asian countries have successfully transformed into an international division of labor system, which has facilitated industrial upgrading in Taiwan, intensely rendering trade substitution and complementary trade activities with enterprises in mainland China and Southeast Asian countries. About half of the ESCOs in Taiwan become geared towards international exports in order to seek their sustainable business.

The process of internationalization has been a significant topic for research within academic communities in recent decades. One of the outstanding studies on this topic are those written by scholars from Uppsala University in Sweden, Johanson and Wiedersheim-Paul (1975) and Johanson and Vahlne (1977, 1990, 2006). They have developed the stage theory of corporate internationalization which is also known as the Uppsala Model in terms of the study of Nordic enterprises. Johanson and Vahlne (1977, 1990, 2006) have proposed the concept of Psychic Distance, explaining the behavior of selecting overseas markets from near to farther distance. The theory of internationalization emphasizes the impact of cultural differences and concludes that it is easier for enterprises to succeed in international markets where language, culture, and economic development are relatively closer.

On the other hand, Oviatt and McDougall (1994, 1995, 2000) have focused on the research of Innate Exporters in rapid development of high-tech industry and argued that the enterprises can makes profits due to unique and scarce resources. However, 
the scarce resources are attached to the international organization of enterprises, such as intangible assets or specific talents. In response to this concern, some scholars have studied that firm-specific assets indirectly improve performance through internationalization (Buckley \& Tian, 2017a, 2017b; Kirca et al., 2016). Based on the views above, this study suggests that firm-specific assets of ESCOs, including the firm size, specific products, growth ratio and saving rate, are all correlated with the degree of internationalization; therefore, we propose hypothesis $\mathrm{H}_{1}$ as following:

\section{H1: Firm-specific capabilities of ESCOs impact on the firm's internationalization.}

For decades, international business scholars have studies whether and how internationalization directly improves firm performance. Empirical researches have mixed results and lead to question the theoretical hypotheses by examining the internationalization-performance (I-P) relationship (Buckley \& Tian, 2017a, 2017b). About the degree of internationalization among enterprises often refers to the degree of participation by enterprises in overseas markets, the most commonly used indicators include the proportion of sales in the international markets in accounting to the total sales of the enterprises, the proportion of overseas assets to total assets. However, no consistent conclusion has been reached regarding whether a higher degree of internationalization of the enterprise will result in better firm performance. In a positive linear relationship, the increase in degree of internationalization will bring in higher net income to multinational companies, enabling them to take the lead in the competition with certain advantages.

Verbeke \& Brugman (2009) summarize the literatures related to the degree of internationalization and performance of multinational corporations and believe that this positive correlation comes from the specific advantages of enterprises. Multinational companies have internalized their transaction costs due to international operations. Moreover, they also have the potential to enjoy choices in lower costs and make profit to improve their performance. Compared with other domestic enterprises, the diversification of products from multi-national enterprises will achieve economic scale and economy of scope. As a result, they can effectively promote products to wider markets and even make profits through foreign direct investment. Wu et al. (2012) have also observed that enterprises with considerable scale of oversea sales reveal a positive linear relationship between the degree of internationalization and business performance. Rugman et al. (2008) infer that if the degree of internationalization is higher, multinational companies will get greater benefits and be able to compete with local companies with specific advantages. Therefore, we propose the additional empirical hypothesis $\mathrm{H}_{2}$ as following:

\section{$\mathrm{H}_{2}$ : The degree of internationalization of ESCOs demonstrates a positive relationship with business performance.}


Evans and Mavondo (2002) and Lei (2007) believe that when companies increase their input of foreign resources in the early stage of internationalization, the differences between the overseas and domestic markets will produce additional transaction costs and risks, and lead to a negative relationship between internationalization and corporate performance. Furthermore, cultural differences will hinder the overseas earnings of the enterprises. Olmos and Vial (2015) analyze the initial stage of internationalization among SMEs, and state that the degree of internationalization and business performance should demonstrate a negative linear relationship.

Consideration of dynamic evolution. Gaur and Kumar (2009) conclude that the operating costs may tend to be relatively higher due to no acquiring with foreign markets in the early stage of corporate internationalization. But over the period of time, international companies will gradually establish learning mechanisms and adapt to local organizations. Therefore, the international business performance of enterprises will soar up (like as positive U-shaped curve). It indicates that the growing trend will reverse once the company has bypassed the watershed (Zhou, 2018).

On the other hand, Qian et al. (2008) believe that, based on the Nordic Uppsala Model, the internationalization process of multinational corporations will actually adapt the order of development from easy to more complicated oversea markets. Therefore, the international business performance first displays rising signs, and then the performance declines and gets worse (treat as inverted U-shaped curve). As for an inverted U-shaped curve relationship, it is not a monotonous linear relationship between international operations and corporate performance. Multinational corporations are confronted with relatively lower overseas uncertainty and management costs in the early stage, which is conducive to the realization of international benefits. However, when internationalization deepens, a series of uncertainties and management costs will lead to a decline in corporate performance. In other words, the overall performance will first rise and then fall. Chen et al. (2014), Fernhaber and McDougall (2014) believe that the curve slope regarding the degree of internationalization and performance relationship is initially positive, but when the degree of internationalization passes through the optimum point, the curve slope is expected to start turning negative, exhibiting an inverted U-shaped relationship. This optimum point is called the international inflection point and is usually distributed within the range of 50\% to $80 \%$. Therefore, we test the additional empirical hypothesis $\mathrm{H}_{3}$ as following:

\section{H3: The degree of internationalization of ESCOs is revealed in a non-linear relationship with their business performance.}

Furthermore, the diversified resources (Chen et al., 2014), the scale of business operations (Wu et al., 2012; Zhou, 2018), the speed of international expansion (Olmos and Vial, 2015), and high-tech features (Fernhaber and McDougall, 2014) owned by multi-national enterprises have overall been found to exert a relatively 
significant impact on international business performance. According to these studies, we propose the integrated empirical hypothesis $\mathrm{H}_{4}$ as following:

\section{H4: Firm-specific capabilities of ESCOs impact on the firm's performance.}

\section{Model Building}

According to the definition of mediators in Baron and Kenny (1986) and Helm and Mark (2012), our study treats internationalization as the mediator on financial performance for ESCO-specific assets, including capital, ESCO projects, net income ratio, growth rate, energy saving rate and ESCO-types, to observe how they further influence the firm's financial performance through international decisions. We assents the argument of Hitt et al. (2006) that firms require firm-specific assets to engage international expansion.

The empirical analysis according to the analytic procedure for mediator variables (see Figure 1), this study discusses the relationship between the ESCO-specific capabilities and firm performance, and introduces the internationalization as mediatory variable to test if the four hypotheses $\left(\mathrm{H}_{1}, \mathrm{H}_{2}, \mathrm{H}_{3}\right.$, and $\left.\mathrm{H}_{4}\right)$ are significant. If the four hypotheses are confirmed, they indicate that ESCO-specific capabilities will affect the financial performance through internationalization. By the mediational structure, we can also estimate the direct and indirect effects, to further observe the influence level of internationalization in ESCO industry as shown in Figure 1.

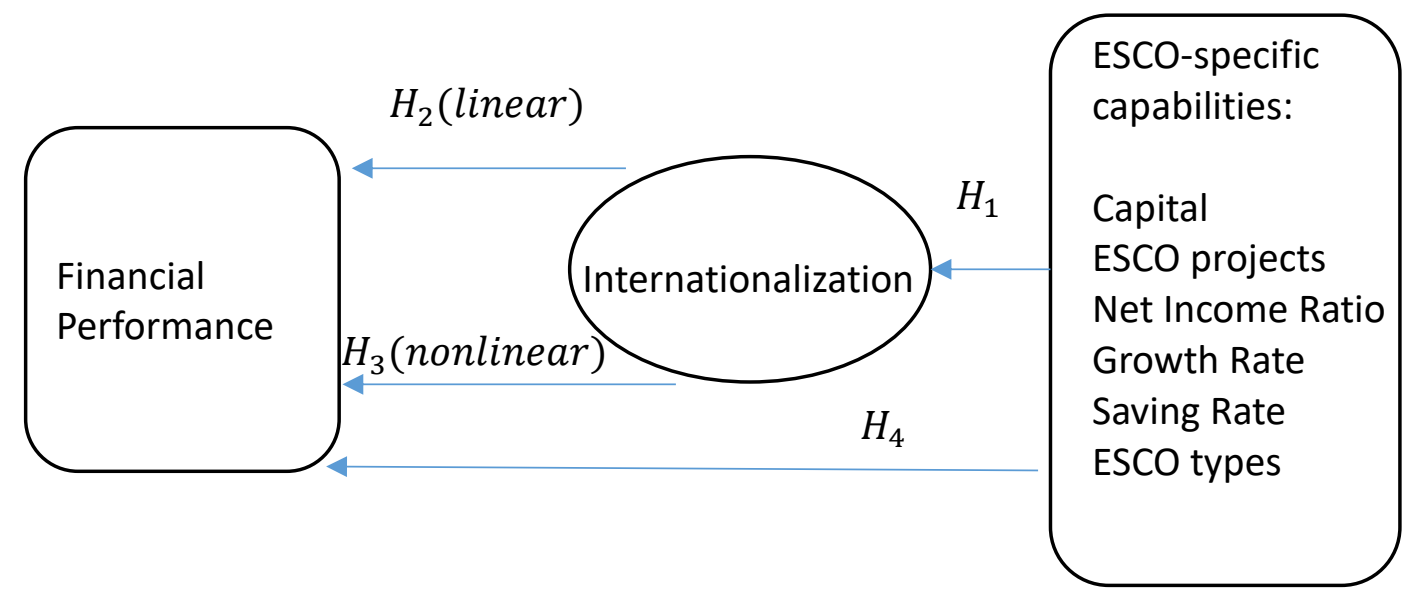

Figure 1: The mediational structure in internationalization-performance model

Firstly, we think that ESCO-specific capabilities, tangible or intangible, can help firms expand internationally by devoting themselves competitive advantages in foreign markets. The specific capabilities may be unique to individual industries, because different industries may rely on different bundle of resources to take the advantages. That is to say, we have to examine the relationship between ESCO- 
specific capabilities and internationalization. According to the mediational procedure of Baron and Kenny (1986), the model for the influences of ESCOspecific capabilities on the degree of internationalization (Model I) is set up to test $H_{1}$ as follows:



$i=1,2, \ldots$, n company

$\varepsilon_{i}:$ The error term of the whole model $\sim \operatorname{iid}\left(0, \sigma_{\varepsilon}^{2}\right)$

The proxy variable for internationalization is the degree of internationalization (=the oversea sales/ the whole sales); the ESCO-specific capabilities is considered for ESCO capital; ESCO sales, the net income ratio of ESCO projects, growth rate of ESCO sales, the energy saving rate and the ESCO type (1: franchise, 2: equipment, and 3: peripheral services). If $H_{l}$ is confirmed, we can conclude that ESCO-specific capabilities impact on the extension of internationalization, and recognize the influential level of those factors.

Based on Figure 1, in order to observe the mediational effects internationalization, this study constructs another model of internationalization on firm performance (Model II) to test $H_{2}$ as follows:

$F P_{i}=\beta_{0}+\beta_{1}$ Internationalization $_{i}+\varepsilon_{i}$

In equation (2), since Taiwan ESCOs mainly belong to small-and-medium enterprises, their market values of firms are not easy to acquire. We adopt the net income as the proxy variables of financial performance (abbreviated as FP). This $\beta_{l}$ is used to observe the linear relationship between financial performance and the degree of internationalization. If $H_{1}$ and $H_{2}$ are confirmed, the mediational effect would be allowed, we can conclude that ESCO-specific capabilities impact on the extension of internationalization, and furthermore influence the business performance.

Some scholars think that the degree of internationalization of ESCOs is revealed a non-linear relationship with their business performance. This study constructs another empirical model of internationalization on firm performance (Model III) to test $H_{3}$ as follows:

$F P_{i}=\beta_{0}+\beta_{1}$ Internationalization $_{i}+\beta_{2}$ Internationalization $_{i}^{2}+\varepsilon_{i}$

If $\beta_{1}$ and $\beta_{2}$ of the model III can be significantly estimated, one can observe the relationship between the degree of internationalization of ESCOs with its business performance from the positive or negative signs of the estimates. In the case of $\beta_{2} \sim 0$, and $\beta_{1}>0$, it indicates that the relationship between the degree of internationalization of enterprises with its business performance should display 
positive linearity in which a business is most likely to perform better with a higher degree of internationalization. In the case of $\beta_{2} \sim 0$, and $\beta_{1}<0$, it denotes that the relationship between the degree of internationalization of enterprises with its business performance should display negative linearity which means a higher degree of internationalization leads to a worse performance of a firm. However, if $\beta_{2}<0$, and $\beta_{1}>0$, it points that the relationship should display an inverted U-shape mode. At the initial stage of internationalization, when the degree of internationalization is enhanced, the business performance of the enterprise will be better. However, when the degree of internationalization continues to enhance and exceeds a certain saturation point, the overall relationship will be reversed. Once the degree of internationalization is further enhanced, the business performance is expected to worsen. In contrast, if $\beta_{2}>0$ and $\beta_{1}<0$, it indicates that the relationship should result in a U-shaped display. At the initial stage of corporate internationalization, when the degree of internationalization is enhanced, the business performance of the enterprise will worsen. However, when the degree of internationalization is further enhanced, the business performance of the enterprise will be reversed and improved.

Furthermore, since the study of ESCO industry in Taiwan is a small-sample industrial survey, the number of samples is only limited on data from a few hundred enterprises. If one would like to estimate the relationship form of the S-type, it is necessary to estimate the cubed of international degree. Due to insufficient samples, this study has only resorted to the quadratic term to estimate the non-linear relationship.

Based on Figure 1, the more ESCO-specific capabilities act as strategic resources to improve financial performance. Once the $H_{1}$ and $H_{2}$ hypotheses are confirmed, we also construct another empirical model of ESCO-specific capabilities on firm performance (Model IV) to test $\mathrm{H}_{4}$ as follows:

$$
F P_{i}=\gamma_{0}+\gamma_{1} E S C O-\text { specific Capabilities }{ }_{i}+\varepsilon_{i}
$$

In order to calculate the mediational effects of internationalization, the empirical Model V, compared to Model IV, is designed as follows:

$$
\begin{aligned}
F P_{i}= & \delta_{0}+\delta_{1}{\text { ESCO }- \text { specific Capabilities }_{i}} \\
& +\delta_{2} \text { Internationalization }_{i}+\delta_{3} \text { Internationalization }_{i}^{2}+\varepsilon_{i}
\end{aligned}
$$

Basing to the definition of mediator by Baron and Kenny (1986) and Holmbeck (2002), The difference, $\left(\gamma_{1}-\delta_{1}\right)$, of the regression coefficients for the same explanatory variables in the two models of equation (4) and (5), indicates the influence of the dependent variables after the introduction of mediators. Accordingly, this study adopts the extent of gap for regression coefficients $\left(\left(\gamma_{1}-\right.\right.$ $\left.\left.\delta_{1}\right) / \gamma_{1}\right)$ as the mediational effect, and the rest of the influencing effects, $\left(\delta_{1} / \gamma_{1}\right)$, as the direct effect of ESCO-specific capabilities on the firm's financial 
performance.

\section{Internationalization-Performance Relationship}

We conduct the survey in the Taiwan ESCO industry for some years under the projects of Taiwan Green Productivity Foundation. We find that the domestic ESCO projects values are gradually saturated, and the ESCO exports become important development for some ESCOs. Because ESCOs mostly belong to small-andmedium enterprises and the internationalization is the core strategy, it is suitable context for exploring how ESCO-specific capabilities enable and mediate the internationalization-performance relationship. This study investigates the business operations and international output characteristics of the ESCOs in Taiwan from 2016 to 2019. A total of 355 companies were interviewed and surveyed in this given period. The companies are outstand enterprises for ESCO projects executing and recommended by Taiwan Energy Service Association to survey in this study, they accounted for $33.65 \%$ of all its members. 
Table 1: The relative variables in the empirical analysis

\begin{tabular}{|c|c|c|}
\hline Items & Titles & Definition \\
\hline \multirow[t]{6}{*}{$\begin{array}{l}\text { Dependent } \\
\text { Variables: } \\
\text { ESCO-specific } \\
\text { capabilities }\end{array}$} & Capital & $\begin{array}{l}\text { Corporate capital is defined as } \\
\text { the mix of assets or resources } \\
\text { which ESCO can draw in } \\
\text { financing its business. }\end{array}$ \\
\hline & ESCO Projects & $\begin{array}{l}\text { ESCO Projects is the amount of } \\
\text { revenue which a company } \\
\text { executes ESCO projects in one } \\
\text { year period. }\end{array}$ \\
\hline & Net Income Ratio & $\begin{array}{l}\text { The net income ratio is the ratio } \\
\text { of after-tax profits to net sales in } \\
\text { ESCO projects. }\end{array}$ \\
\hline & Growth Rate & $\begin{array}{l}\text { Growth rate refers to the } \\
\text { percentage change of ESCO } \\
\text { Sales within a year. }\end{array}$ \\
\hline & Saving Rate & $\begin{array}{l}\text { Saving Rate is the percentage of } \\
\text { the annual reduction of energy } \\
\text { use due to ESCO projects. }\end{array}$ \\
\hline & ESCO types & $\begin{array}{l}\text { 1: franchise, 2: equipment, and 3: } \\
\text { peripheral services of ESCO }\end{array}$ \\
\hline \multirow[t]{3}{*}{ Mediators } & $\begin{array}{l}\text { Internationalization } \\
(\%)\end{array}$ & $\begin{array}{l}\text { Internationalization }(\%) \\
\text { measured as the ratio of oversea } \\
\text { sales to the whole sales. }\end{array}$ \\
\hline & China (\%) & $\begin{array}{l}\text { China (\%) is measured as the } \\
\text { ratio of the sales in China region } \\
\text { to the sales in oversea. }\end{array}$ \\
\hline & Asia (\%) & $\begin{array}{l}\text { Asia }(\%) \text { is measured as the ratio } \\
\text { of the sales in Southeast Asian } \\
\text { region to the sales in oversea. }\end{array}$ \\
\hline $\begin{array}{l}\text { Independent } \\
\text { Variables }\end{array}$ & Profits & $\begin{array}{l}\text { Profits are calculated as total } \\
\text { revenue less total expenses. }\end{array}$ \\
\hline
\end{tabular}

Following the structure of mediation, we adopt the three kinds of variables in our study. The dependent variables are designed as ESCO-specific capabilities as Table 1 shows, we will test their significance about international output. Table 2 shows the resource characteristics of the analysis including firm capital, annual volume of ESCO projects, net income ratio, annual growth rate, energy saving rate, and ESCO-types. According to the analysis, the most resource characteristics are all significantly different between domestic and international ESCOs, except for ESCO types. The companies with 
international output own significantly better resource characteristics than those without international output. This result also shows that if the government emphasizes on promoting international output, they should focus on companies with more resource advantages which include stronger marketing abilities, larger ESCOs, stronger profitability, and more efficient energy-saving projects. Giving bonus or incentives can promote business internationalization.

Table 2: The significant analysis of ESCO-specific capabilities

\begin{tabular}{|l|r|r|r|r|r|}
\hline \multirow{2}{*}{ Group } & \multicolumn{2}{|c|}{ Domestic ESCOs } & \multicolumn{2}{c|}{ International ESCOs } & \multicolumn{1}{c|}{$\begin{array}{c}\text { ANOVA } \\
\text { F-test }\end{array}$} \\
\cline { 2 - 7 } & \multicolumn{1}{|c|}{ means } & \multicolumn{1}{c|}{ stdev } & \multicolumn{1}{c|}{ means } & \multicolumn{1}{c|}{ stdev } & \\
\hline Capital (US\$ K) & 735.17 & 2519.01 & 1422.25 & 3800.11 & $4.12 *$ \\
\hline ESCO Projects (US\$ K) & 102.07 & 268.19 & 306.61 & 604.54 & $18.27 * * *$ \\
\hline Net Income Rate (\%) & 8.70 & 13.12 & 11.89 & 13.64 & $5.015^{*}$ \\
\hline Growth Rate (\%) & -4.32 & 21.82 & 2.83 & 22.95 & $8.928 * *$ \\
\hline Saving Rate (\%) & 27.28 & 17.48 & 30.89 & 16.60 & $3.776^{*}$ \\
\hline ESCO types & 2.39 & 0.69 & 2.35 & 0.69 & 0.23 \\
\hline Sample Sizes & 200 & & 155 & 355 \\
\hline
\end{tabular}

Note: $*$ at $5 \%$ level of significance, ${ }^{* *}$ at $1 \%$ level of significance, ${ }^{* * *}$ at $0.1 \%$ level of significance

As for mediators, we introduce three variables defined in Table 1 to observe the mediational effects. Furthermore, oversea operating areas are chosen primarily due to labor costs or ability to facilitate international trade (Obst, 2013). Recently, China is the main export region of Taiwan's ESCOs which accounted for about $40 \%$ of the total ESCO export. In addition, exports in Southeast Asian countries, including Vietnam, Thailand and Philippines, Indonesia and Malaysia, are about $40 \%$. Therefore, our study adopt China (\%) and Asia $(\%)$ to be other proxy mediators to realize the influence of export to overseas. As for dependent variables, return on assets (ROA) is not possible accepted since ESCOs mostly belong to small-and-medium enterprises and they do not disclose their relative balance sheet data. We also note that some research suggest that return on sales (ROS) may not a reliable measure of performance (Miller and Shamsie, 2001). Then we measure the profits per annul to be the proxy of performance.

Finally, Taiwan's ESCOs can be divided into three types of business operations, including: energy-saving franchise companies, energy-saving equipment companies, and energy-service peripheral companies. This study surveyed 42 energy-service franchise companies with the overall business activities consisting of energy services. The next kind is the energy-saving equipment companies which are equipment manufacturers. There are 138 
ESCOs to also engage in energy-saving projects. The third one is classified as energy-service peripheral companies which are general related companies, such as telecom-companies, leasing company, engineering planning companies...etc. The ESCO-type index is design as the control variable to observe the changes in secondary ESCO industries.

Table 2 contains descriptive statistics. The all specific capabilities of international ESCOs perform better than the ones of domestic companies. On the other hand, to test and avoid collinearity between the explanatory variables, this study performs Pearson correlation coefficient test on the explanatory variables; the results are organized on Table 3. The Pearson correlation coefficient results show that there are significant correlation with profits. However, the correlations among dependent variables are only $0.104 \sim 0.371$, which are weak correlative.

Table 3: The correlation analysis of relative variables

\begin{tabular}{|c|c|c|c|c|c|c|c|c|c|c|}
\hline Correlation & Capital & $\begin{array}{l}\text { ESCO- } \\
\text { project }\end{array}$ & $\begin{array}{c}\text { NI Rate } \\
\%\end{array}$ & \begin{tabular}{|c} 
Growth \\
Rate \\
\end{tabular} & $\begin{array}{c}\text { Saving } \\
\text { Rate }\end{array}$ & $\begin{array}{c}\text { ESCO } \\
\text { types }\end{array}$ & International & $\begin{array}{c}\text { China } \\
\%\end{array}$ & $\begin{array}{c}\text { Asia } \\
\% \\
\end{array}$ & Profit \\
\hline Capital & 1.000 & ----- & ----- & ----- & ----- & ----- & ----- & ---- & ---- & ----- \\
\hline $\begin{array}{l}\text { ESCO- } \\
\text { projects }\end{array}$ & $0.371 * * *$ & 1.000 & ----- & ----- & ----- & ----- & ----- & ----- & ----- & ----- \\
\hline NI Rate \% & -0.013 & 0.078 & 1.000 & ----- & ----- & ----- & ----- & ----- & ----- & ----- \\
\hline Growth Rate & 0.044 & $0.129 *$ & $0.104^{*}$ & 1.000 & ----- & ----- & ----- & ----- & ---- & ---- \\
\hline Saving Rate & -0.015 & 0.050 & 0.092 & 0.067 & 1.000 & ----- & ----- & ----- & ----- & ----- \\
\hline ESCO types & $0.120 *$ & -0.102 & $\begin{array}{c}- \\
0.216^{*} * * \\
\end{array}$ & -0.100 & $-0.133^{*}$ & 1.000 & ----- & ---- & ----- & ----- \\
\hline International & 0.006 & -0.001 & $0.146 * *$ & $0.110^{*}$ & 0.074 & -0.026 & 1.000 & ----- & ----- & ----- \\
\hline China \% & $0.125^{*}$ & $0.123^{*}$ & $0.126^{*}$ & $0.133^{*}$ & $0.162 * *$ & 0.008 & $0.184 * *$ & 1.000 & ----- & ----- \\
\hline Asia \% & $0.129 *$ & $0.150 * *$ & 0.017 & 0.058 & 0.089 & 0.036 & $0.149 * *$ & 0.093 & 1.000 & ----- \\
\hline Profits & $0.197 * * *$ & $0.776 * * *$ & $0.385 * * *$ & $0.158 * *$ & 0.054 & $-0.20 * * *$ & $0.110^{*}$ & $0.174 * *$ & $0.118 *$ & 1.000 \\
\hline
\end{tabular}

Note: $*$ at $5 \%$ level of significance, ${ }^{* *}$ at $1 \%$ level of significance, ${ }^{* * *}$ at $0.1 \%$ level of significance

Table 4 shows the results in Model I for Hypothesis 1, which states that specific capabilities of ESCOs impact on the firm's degree of internationalization. Especially for net income ratio, growth rate and saving rate, they significantly impact on international strategies, which provides tentative support for Hypothesis 1. The more capabilities, the more degree of internationalization. This coefficient suggests that a $1 \%$ increase in ESCO-specific capabilities produces about $0.103 \sim 0.308 \%$ increase in export.

The design of Model II is to observe and test if $\mathrm{H}_{2}$ (the degree of internationalization of ESCOs demonstrates a positive relationship with business performance) is significant. As showed in Table 4, all mediators demonstrate positive relationship with business performance. The model fitness for internationalization: $\mathrm{F}=4.379^{*}$; 
the model fitness for China (\%): $\mathrm{F}=8.870^{* *}$ and Asia (\%): 4.998**. We can conclude that developing oversea markets increase business performance in ESCO industry.

Model III observes and tests if $\mathrm{H}_{3}$ (the degree of internationalization of ESCOs is revealed in a non-linear relationship with their business performance) is significant. As showed in Table 4, the degree of internationalization cannot display significantly nonlinear relationship with business performance. However, the market share in China appears significantly nonlinear connection with profit. Due to $\beta_{1}>0$ and $\beta_{2}<0$, it points that the relationship displays an inverted $U$-shape mode. At the initial stage of internationalization, when the percentage of China (=the sales in China / the sales in oversea) is enhanced, the business performance of the enterprise will be better. At once China (\%) continues to increase and exceeds a certain saturation point $\left(=\frac{\beta_{1}}{2 \beta_{2}}=\frac{42.698}{2 \times 0.393}=54.323(\%)\right)$, the overall relationship will be reversed as shown in Figure 2(a) (the test can be referred as Lind and Mehlum, 2010). The business performance is observed to worsen. Similarly, the study points that the relationship should display an inverted U-shape mode in Figure 2 (b) in Southeast Asia export. At the initial stage of internationalization, when the percentage (=the sales in Southeast Asia / the sales in oversea) is enhanced, the business performance of the enterprise will be better. However, when the Asia (\%) continues to increase and exceeds a certain saturation point $\left(=\frac{\beta_{1}}{2 \beta_{2}}=\frac{43.634}{2 \times 0.440}=49.584(\%)\right)$.

Since $\mathrm{H}_{1}, \mathrm{H}_{2}$ and $\mathrm{H}_{3}$ are confirmed significantly, the index about internationalization behaves as mediational roles in our research structure. We adopt Model IV and Model V to measure the mediational effects of ESCO-specific capabilities through internationalization. As shown in Table 5, comparing with Model IV and Model V1 , we can find minor effects from the degree of internationalization. The $0.590 \% \sim 3.098 \%$ of mediational effects represent roughly that the large-capital and large-project energy service companies (ESCOs) can increase 0.590\% 3.098\% firm profits by developing internationalization, but internationalization play an important role for the ESCOs with higher saving rate or higher growth rate, the mediational effects are about $11.869 \%$ 35.507\%.

In addition, our study use China (\%) and Asia (\%) to be mediators in our research. Comparing with Model V-1 and Model V-2, all mediational effects become important in China area. For example, the mediational effects of large firm by China (\%) increase from $4.532 \%$ to $80.159 \%$. Due to the samples from Taiwan, the ESCOs mainly rely on the export to mainland China in recent decades. The large-capital, numerous-ESCO sales, high-earning firms frequently develop the energy service markets in China. Therefore, the mediational effects from China (\%) are superior to the one from the degree of internationalization. Similarly, comparing with Model V-1 and Model V-3 (Southeast Asia region), all mediational effects increase slightly. For example, the mediational effect of net income rate by internationalization change from $2.242 \%$ to $3.462 \%$. Totally, we can find the influence level of China $(\%)$ is more than the degree of internationalization and Southeast Asia (\%). 


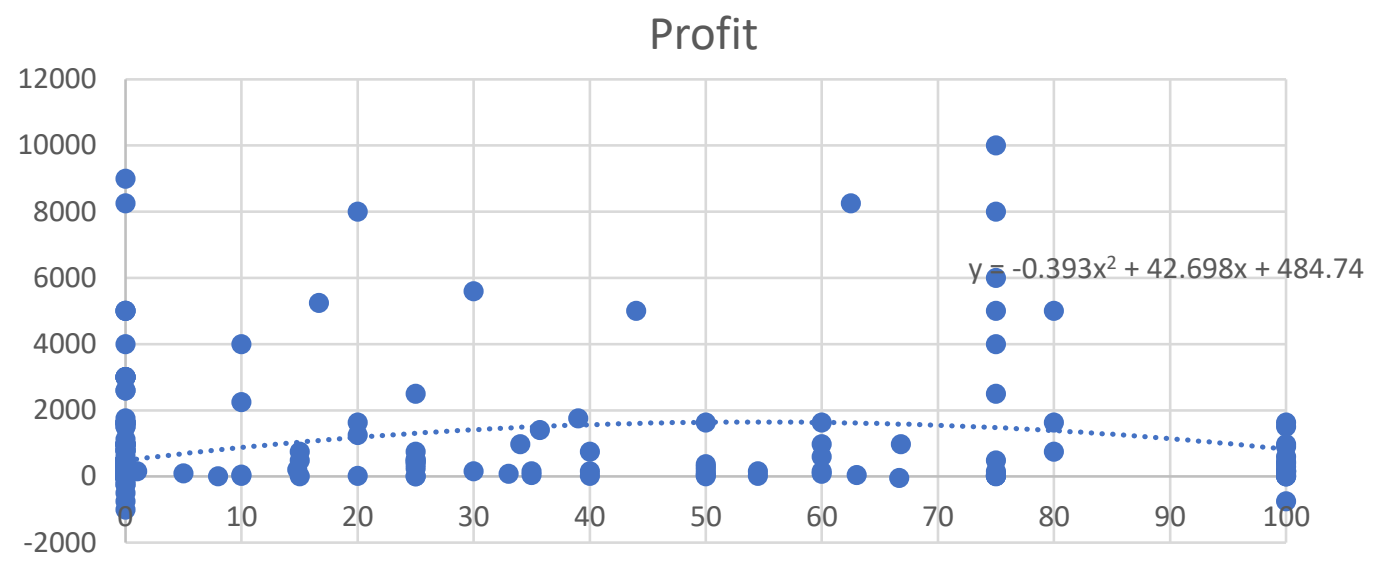

1. Curve in the graph : Energy-saving project net interest rate $=42.698 \mathrm{x}(\mathrm{China} \%)-$ $0.393 x(\text { China \% })^{2}$

2. Curve apex $=54.323(\%)=42.698 /(2 \times 0.393)$

Figure 2(a): The relationship between profit and the export proportion in China

\section{Profit}

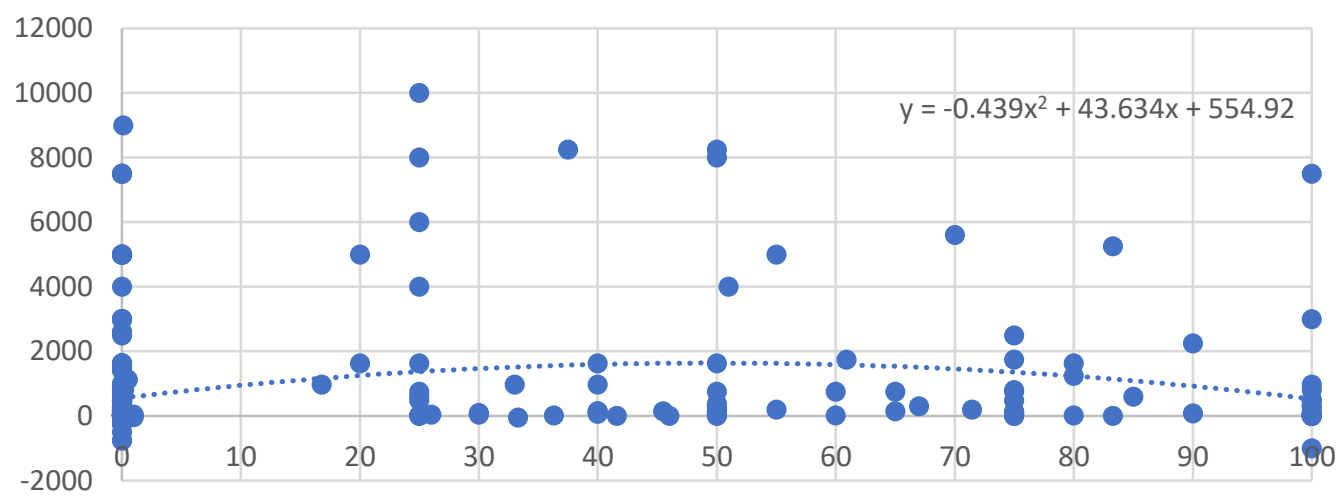

1. Curve in the graph : Energy-saving project net interest rate $=43.634 \mathrm{x}$ (Southeast Asia \%)

- $0.439 x$ (Southeast Asia \%)2

2. Curve apex $=49.584(\%)=43.634 /(2 \times 0.439)$

Figure 2(b): The relationship between profit and the export proportion in Southeast Asia 
Table 4: The Estimations of Model I III

\begin{tabular}{|c|c|c|c|c|c|c|c|}
\hline Variables & Model I & \multicolumn{3}{|c|}{ Model II } & \multicolumn{3}{|c|}{ Model III } \\
\hline & International & \multicolumn{3}{|c|}{ Profit } & \multicolumn{3}{|c|}{ Profit } \\
\hline Intercept & 4.992 & $675.185 * * *$ & $571.400 * * *$ & $631.579 * * *$ & $1346.841 * * *$ & $484.743 * * *$ & $554.918 * * *$ \\
\hline Capital (US\$ K) & $1.313 \mathrm{E}-5$ & & & & & & \\
\hline Net Income Rate (\%) & $0.308^{*}$ & & & & & & \\
\hline Growth Rate $(\%)$ & $0.151 *$ & & & & & & \\
\hline Saving Rate $(\%)$ & $0.103 *$ & & & & & & \\
\hline Internationalization & & $5.760 *$ & & & $-14.224 *$ & & \\
\hline Internationalization2 & & & & & $0.065 * *$ & & \\
\hline China & & & & & & $42.693 * * *$ & \\
\hline China2 & & & $0.025 * *$ & & & $-0.390 * *$ & \\
\hline Asia & & & & $6.480 *$ & & & $43.634 * * *$ \\
\hline Asia2 & & & & & & & $-0.440 * * *$ \\
\hline $\mathrm{R} 2$ & 0.035 & 0.012 & 0.03 & 0.014 & 0.027 & 0.064 & 0.049 \\
\hline adjusted R2 & 0.021 & 0.009 & 0.027 & 0.011 & 0.021 & 0.057 & 0.044 \\
\hline F-test & $2.415^{*}$ & $4.379 *$ & $8.870 * *$ & $4.998 *$ & $4.856 * *$ & $9.638 * * *$ & $9.113 * * *$ \\
\hline
\end{tabular}

Note: $*$ at $5 \%$ level of significance, $* *$ at $1 \%$ level of significance, $* * *$ at $0.1 \%$ level of significance 
Table 5: The estimation of Mediational Effects

\begin{tabular}{|c|c|c|c|c|c|c|c|}
\hline \multirow{2}{*}{ Variables } & \multirow{2}{*}{$\begin{array}{c}\text { Model IV } \\
\text { Profit }\end{array}$} & \multicolumn{2}{|c|}{$\begin{array}{c}\text { Model V } \\
\text { (Internationalization) }\end{array}$} & \multicolumn{2}{|c|}{ Model V (China) } & \multicolumn{2}{|c|}{ Model V (Southeast Asia) } \\
\hline & & Profit & $\begin{array}{l}\text { Mediational } \\
\text { Effect }\end{array}$ & Profit & $\begin{array}{l}\text { Mediational } \\
\text { Effect }\end{array}$ & Profit & $\begin{array}{c}\text { Mediational } \\
\text { Effect }\end{array}$ \\
\hline Intercept & -115.228 & -109.944 & $4.586 \%$ & -133.048 & $15.46 \%$ & -110.631 & $3.99 \%$ \\
\hline Capital (US\$ K) & $-0.002 * * *$ & $-0.002 * * *$ & $3.098 \%$ & $-0.003 * * *$ & $37.42 \%$ & $-0.002 * * *$ & $2.49 \%$ \\
\hline ESCO projects (US\$ K) & $0.098 * * *$ & $0.098^{* * *}$ & $0.590 \%$ & $0.109 * * *$ & $11.10 \%$ & $0.0976 * * *$ & $0.62 \%$ \\
\hline Net Income Rate $(\%)$ & $40.063 * * *$ & $39.165 * * *$ & $2.242 \%$ & $38.248 * * *$ & $4.53 \%$ & $38.676 * * *$ & $3.46 \%$ \\
\hline Growth Rate $(\%)$ & 2.118 & 1.366 & $35.507 \%$ & 1.694 & $20.05 \%$ & 1.851 & $12.61 \%$ \\
\hline Saving Rate $(\%)$ & -1.746 & -1.953 & $11.869 \%$ & -3.145 & $80.16 \%$ & -2.696 & $54.47 \%$ \\
\hline Internationalization & & -1.237 & & & & & \\
\hline Internationalization2 & & $0.019 * *$ & & & & & \\
\hline China & & & & $9.713 *$ & & & \\
\hline China2 & & & & $-0.079 *$ & & & \\
\hline Asia & & & & & & $16.403 * *$ & \\
\hline Asia2 & & & & & & $-0.190 * *$ & \\
\hline $\mathrm{R} 2$ & 0.708 & 0.713 & & 0.672 & & 0.714 & \\
\hline adjusted R2 & 0.704 & 0.708 & & 0.663 & & 0.708 & \\
\hline F-test & $160.549 * * *$ & $136.503 * * *$ & & $78.855 * * *$ & & $117.621 * * *$ & \\
\hline
\end{tabular}

Note: $*$ at $5 \%$ level of significance, $* *$ at $1 \%$ level of significance, $* * *$ at $0.1 \%$ level of significance 
Since $\mathrm{H}_{1}, \mathrm{H}_{2}$ and $\mathrm{H}_{3}$ are confirmed significantly, the index about internationalization behaves as mediational roles in our research structure. We adopt Model IV and Model V to measure the mediational effects of ESCO-specific capabilities through internationalization. As shown in Table 5, comparing with Model IV and Model V1 , we can find minor effects from the degree of internationalization. The $0.590 \% \sim 3.098 \%$ of mediational effects represent roughly that the large-capital and large-project energy service companies (ESCOs) can increase 0.590\% 3.098\% firm profits by developing internationalization, but internationalization play an important role for the ESCOs with higher saving rate or higher growth rate, the mediational effects are about $11.869 \% \sim 35.507 \%$.

In addition, our study use China (\%) and Asia (\%) to be mediators in our research. Comparing with Model V-1 and Model V-2, all mediational effects become important in China area. For example, the mediational effects of large firm by China $(\%)$ increase from $4.532 \%$ to $80.159 \%$. Due to the samples from Taiwan, the ESCOs mainly rely on the export to mainland China in recent decades. The large-capital, numerous-ESCO sales, high-earning firms frequently develop the energy service markets in China. Therefore, the mediational effects from China (\%) are superior to the one from the degree of internationalization. Similarly, comparing with Model V-1 and Model V-3 (Southeast Asia region), all mediational effects increase slightly. For example, the mediational effect of net income rate by internationalization change from $2.242 \%$ to $3.462 \%$. Totally, we can find the influence level of China $(\%)$ is more than the degree of internationalization and Southeast Asia (\%).

\section{Conclusion and Discussion}

This study analyzes the energy saving business and export characteristics of ESCOs in Taiwan from 2016 to 2019 . The 355 companies have taken part in the surveying process, which was determined by classification in terms of area and capital amount. The surveyed enterprises provide an overall representation of the industry.

In terms of international output, domestic energy saving market is simply not enough to accommodate all ESCOs, so approximately half of them have resorted to international export, adopting international trade, international strategic alliances, and international business operations in order to maintain growth needs. Based on relevant theories of internationalization, our study has verified four hypothesis and confirmed four internationalization phenomena with regard to Taiwan's ESCOs.

First, for international output of Taiwan's ESCOs, those firms with more specific resources, it will be easier to promote the international energy-saving businesses. The resources are confirmed as firm capital, annual ESCO sales, net income ratio, annual growth rate, energy saving rate. Secondly, if the degree of internationalization of ESCOs is greater, the overall profitability of enterprises is also relatively higher.

The third is that internationalization and profitability of ESCOs display a non-linear relationship which means that when the export ratio is low, the profit from energy service projects of enterprises increases; however, when the ratio exceeds the 
optimal point, about $49.584 \%$ 54.323\%, it will have a reversed phenomenon because overseas operation costs including personnel costs, information costs, and others are relatively higher.

Finally, we derive some models to measure the mediational effects of ESCOspecific capabilities through internationalization. Our results find minor effects from the degree of internationalization. The large-capital and large-project energy service companies (ESCOs) can increase $0.590 \% \sim 3.098 \%$ firm profits by developing internationalization, but internationalization play an important role for the ESCOs with higher saving rate or higher growth rate, the mediational effects are about $11.869 \% \sim 35.507 \%$. Due to the surveyed samples from Taiwan, the ESCOs mainly rely on the export to mainland China in recent decades. The large-capital, numerous-ESCO sales, high-earning firms frequently develop the energy service markets in China. Therefore, we can find the influence level of China (\%) is the most of all regions.

Since ESCOs play the heart of innovative business of energy efficiency, China's ESCO market continues to underpin the global energy saving activities. Our study offers practice insights for Taiwan's ESCO managers who are focused on improving their international performance. We suggests that managers also need to consider industrial specificities in decisions of resources allocation to enhance international strategies. In addition, appropriate export proportion in core oversea markets, especially for China's market, has to be designed and arrangement, over-reliance on some foreign markets may causes negative effects. 


\section{References}

[1] Baron, R.M. and Kenny, D.A. (1986). The moderator-mediator variable distinction in social psychological research: conceptual, strategic, and statistical considerations. Journal of Personality and Social Psychology, 51, 6, pp. 1173-1182.

[2] Buckley, P. and Tian, X. (2017a). Internationalization theory and the performance of emerging-market multinational enterprises. International Business Review, 26, 5, pp. 976-990.

[3] Buckley, P. and Tian, X. (2017b). Transnationality and financial performance in the era of the global factory. Management International Review, 57, 4, pp. 501-528.

[4] Chen, Y., Jiang, Y., Wang, C. and Hsu, W.C. (2014). How do resources and diversification strategy explain the performance consequences of internationalization? Management Decision, 52, 5, pp. 897-915.

[5] Evans, J. and Mavonda, F.T. (2002). Psychic distance and organizational performance: An empirical examination of international retailing operations. Journal of Business Studies, 33, 3, pp. 515-532.

[6] Fernhaber, S.A. and McDougall, P.P. (2014). Is more always better? Risk trade-offs among Internationalizing new Ventures. European Business Review, 26, 5, pp. 406-420.

[7] Helm, R. and Mark, A. (2012). Analysis and evaluation of moderator effects in regression models: State of art, alternatives and empirical example. Review of Managerial Science, 6, 4, pp. 307-332.

[8] Hitt, M. L., Bierman, K.U. and Shimizu, A. (2006). The Importance of recourses in the internationalization of professional service firms: the good, the bad and the ugly. Academy of Management Journal, 49, 6, pp. 1137-1157.

[9] International Energy Agency. (2018). Energy Efficiency 2018. International Energy Agency, Organization for Economic Cooperation and Development.

[10] Johanson, J. and Vahlne, J.-E. (1977). The internationalization process of the firm - A model of knowledge development and increasing foreign market commitment. Journal of International Business Studies, 8, 1, pp. 23-32.

[11] Johanson, J. and Vahlne, J.-E. (1990). The mechanism of internationalization. International Marketing Review, 7, 4, pp. 11-24.

[12] Johanson, J. and Vahlne, J.-E. (2006). Commitment and opportunity development in the internationalization process: A note on the Uppsala internationalization process model. Management International Review, 46, 2, pp. $165-178$.

[13] Johanson, J. and Wiedersheim-Paul, F. (1975). The internationalization of the firm: Four Swedish cases. Journal of Management Studies, 12, 3, pp. 305-322.

[14] Kirca, A., Femandez, W. and Kundu, S. (2016). An empirical analysis and extension of internalization theory of emerging markets: The role of firmspecific assets and asset dispersion in the multinationality-performance relationship. Journal of World Business, 51, 4, pp. 628-640. 
[15] Lei, L. (2007). Multinationality and performance: A synthetic review and research agenda. International Journal of Management Review, 9, 2, pp. 117139.

[16] Lin, T.C. (2012). ESCO development overview and opportunities. Taiwan Economic Research Monthly, 35, 7, pp. 129-135.

[17] Lind, J.T. and Mehlum, H. (2010). With or without U? The appropriate test for a U-shaped relationship. Oxford Bulletin of Economics and Statistics, 72, 1, pp. 109-118.

[18] Miller, D. and Shamsie, J. (2001). Learning across the life cycle: experimentation and performance among the Hollywood studio heads. Strategic Management Journal, 22, 8, pp. 729-745.

[19] Olmos, M. F. and Vial, I.D. (2015). Internationalization pathways and the SMEs. European Journal of Marketing, 49, 3, pp. 420-443.

[20] Oviatt, B. M. and McDougall, P.P. (1994). Toward a theory of international new ventures. Journal of International Business Studies, 25, 1, pp. 45-64.

[21] Oviatt, B. M. and McDougall, P.P. (1995). Global start-ups: Entrepreneurs on a worldwide stage. Academy of Management Executive, 9, 2, pp.30-44.

[22] Oviatt, B. M. and McDougall, P.P. (2000). International entrepreneurship: The intersection of two research paths. Academy of Management Journal, 43, 5, pp. 902-906.

[23] Tashman, P., Marano, V. and Basin, J. (2019). Firm-specific assets and the internationalization-performance relationship in U.S. movie studio industry. International Business Review, 28, pp. 785-795.

[24] Qian, G., Li, L., Li, J. and Qian, Z. (2008). Regional diversification and firm performance. Journal of International Business Studies, 39, 2, pp. 197-214.

[25] Rugman, A.M., Yip, G.S. and Jayaratne, S. (2008). A note on return on foreign assets and foreign presence for UK multinationals. British Journal of Management, 19, 2, pp. 162-170.

[26] Tashman, P., Marano, V. and Babin, J. (2019). Firm-specific assets and the internationalization-performance relationship in the U.S. movie studio industry. International Business Review, 28, 4, pp.785-795.

[27] Wu, D., Wu, X. and Zhou, H. (2012). International expansion and firm performance in emerging market: Evidence from China. Chinese Management Studies, 6, 3, pp. 509-528.

[28] Yeh, L.J. (2019). Annual Report of Taiwanese Energy Service Industry in 2018. Taiwan Green Productivity Foundation.

[29] Zheng, S., Lam, C.M., Hsu, S.C. and Ren, J. (2018). Evaluating efficiency of energy conservation measures in energy service companies in China. Energy Policy and Economics, 122, 580-591. 